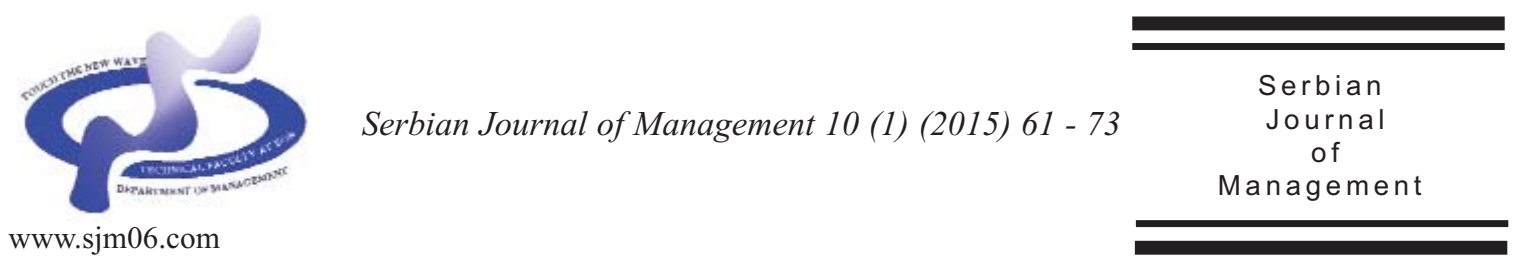

\title{
SELECTION OF NON-CONVENTIONAL MACHINING PROCESSES USING THE OCRA METHOD
}

\author{
Miloš Madić*, Dušan Petković and Miroslav Radovanović \\ Faculty of Mechanical Engineering, University of Niš, A. Medvedeva 14, Niš, Serbia
}

(Received 29 September 2014; accepted 14 January 2015)

\begin{abstract}
Selection of the most suitable nonconventional machining process (NCMP) for a given machining application can be viewed as multi-criteria decision making (MCDM) problem with many conflicting and diverse criteria. To aid these selection processes, different MCDM methods have been proposed. This paper introduces the use of an almost unexplored MCDM method, i.e. operational competitiveness ratings analysis (OCRA) method for solving the NCMP selection problems. Applicability, suitability and computational procedure of OCRA method have been demonstrated while solving three case studies dealing with selection of the most suitable NCMP. In each case study the obtained rankings were compared with those derived by the past researchers using different MCDM methods. The results obtained using the OCRA method have good correlation with those derived by the past researchers which validate the usefulness of this method while solving complex NCMP selection problems.
\end{abstract}

Keywords: non-conventional machining processes, multi-criteria decision making, OCRA

\section{INTRODUCTION}

In recent years there has been an increase of development and application of difficultto-machine materials such as titanium, stainless steel, high-strength temperatureresistant alloys, ceramics, composites, super alloys, etc (Samanta \& Chakraborty, 2011). These materials have wide use in modern industry due to their improved technological and mechanical properties. Although machining of these materials is still viable using conventional machining processes, such as turning, drilling, milling, etc., there

\footnotetext{
* Corresponding author: madic@masfak.ni.ac.rs

DOI:10.5937/sjm10-6802
} 
are situations where these processes are not satisfactory, economical, or even possible (Kalpakjian \& Schmid, 2000). Machining of these materials by conventional machining processes gives rise to problems such as high cutting forces and temperatures, rapid tool wear and residual stresses generated in the workpiece. More rigorous customer demands regarding quality of the end product, as well as manufacturers' strive for cost reduction, have made non-conventional machining processes (NCMPs) even more important in industry.

In today's industry, a large number of NCMPs is applied such as laser beam machining (LBM), abrasive jet machining (AJM), electrical discharge machining (EDM), wire electrical discharge machining (WEDM), plasma arc machining (PAM), electrochemical machining (ECM), ultrasonic machining (USM), electron beam machining (EBM), chemical machining (CHM), etc. From the technological point of view NCMPs are very complex, multi-input multi-output machining processes governed by a large number of machining parameters, and each NCMP posses its own advantages and limitations. A unique characteristic of these processes is that there is no direct contact between the tool and workpiece, as well as the ability to concentrate large amounts of energy per unit area (Kovačević et al., 2014).

Effective utilization of the capabilities of different NCMPs and also maximization of machining performance requires careful selection of the most suitable NCMP for a given work material and shape feature combination (Chakladar \& Chakraborty, 2008; Chakladar et al. 2009; Chatterjee \& Chakraborty, 2013). A particular NCMP found suitable under the given conditions may not be equally efficient under other conditions (Karande \& Chakraborty, 2012). For a given machining application, the selection of the most suitable NCMP requires comprehensive analysis of machining capabilities and characteristics of competitive NCMPs which involves consideration of several conflicting criteria such as maximization of quality, maximization of material removal rate, minimization of cost, etc. Power requirement, tooling and fixtures, tool consumption, safety, work material, shape feature are also recognized as one of the main criteria that influence the NCMP selection of a given machining application. Therefore, selection of the most suitable NCMP is a challenging task (Chakladar et al. 2009), and moreover often a time consuming process (Chatterjee \& Chakraborty, 2013).

In order to facilitate decision making process and provide decision makers with a structured, step-by-step procedure for NCMPs selection, various multi-criteria decision making (MCDM) methods have been proposed in literature. These MCDM methods transform multiple criteria decision making process, i.e., multiple criteria optimization, in a single criterion decision making optimization, which is much easier to solve (Stanujkić et al. 2013).

MCDM is an evaluation framework aimed at evaluation and ranking of a set of alternatives with respect to a set of conflicting criteria considering performance measures of each alternative with respect to each criterion as well as relative significances of the criteria which are represented by criteria weights. Typically criteria weights are determined by decision makers so that the evaluation and ranking of alternatives is performed considering performance measures of alternatives, from one side, and on the other hand, taking into 
account the decision makers preferences of about the relative significance of criteria. Given the evaluation (decision) matrix, decision maker applies certain MCDM method in order to define the evaluation function and obtain a rank order of the alternatives and/or define the utility function and obtain a utility score of the alternatives (Hajkowicz \& Higgins, 2008).

\section{LITERATURE REVIEW}

Most of the past work is related to the development of expert systems, decision support systems and particularly to the application of different MCDM methods for solving NCMPs selection problems. It has to be noted that the majority of the previous studies considered decision matrices from the literature, and only few studies, such as one presented by Temuçin et al. (2013), were focused on the development of decision models for NCMP selection.

Yurdakul and Cogun (2003) proposed a selection procedure for NCMPs based on a combination of analytic hierarchy process (AHP) and technique for order preference by similarity to ideal solution (TOPSIS) methods. AHP method is used to determine the criteria weights, i.e. relative importance of the criteria, whereas TOPSIS method is used to rank each of the feasible NCMPs. Chakraborty and Dey (2006) presented a systematic methodology for selecting the best NCMP under constrained material and machining conditions. The authors also presented the design of an AHP based expert system with a graphical user interface to ease the decision-making process. Chakladar and Chakraborty (2008) proposed the use of a combined approach using the TOPSIS and AHP methods to select the most appropriate
NCMP for a specific work material and shape feature combination. The authors also developed a TOPSIS-AHP based expert system that automates the decision making process with the help of a graphical user interface and visual aids. Chakladar et al. (2009) presented a digraph based approach to ease out the appropriate NCMP selection problem. It includes also the design and development of an expert system that can automate decision making process. Chakraborty (2011) explored the application of a recent MCDM method, i.e. the multiobjective optimization on the basis of ratio analysis (MOORA) method to solve different MCDM problems in manufacturing environment including NCMPs selection problem. Das and Chakraborty (2011) proposed the use of analytic network process (ANP) method to select the most appropriate NCMP for a given machining application taking into account the interdependency and feedback relationships among various criteria affecting the NCMP selection decision. To avoid the difficult and time consuming mathematical calculations of the ANP the authors developed a computer program. Sadhu and Chakraborty (2011) proposed the use of data envelopment analysis (DEA) method for solving NCMP selection problems. The authors considered solving of two case studies and the obtained results proved the applicability, versatility and adaptability of this approach. Karande and Chakraborty (2012) solved four NCMP selection problems using an integrated preference ranking organization method for enrichment evaluation (PROMETHEE) and geometrical analysis for interactive aid (GAIA) method. As noted by the authors this combined methodology is quite simple, easy to understand and releases the process engineers from performing detailed 
mathematical computations. Temuçin et al. (2013) developed a fuzzy based decision support model for NCMP selection by applying TOPSIS and fuzzy TOPSIS methods. Comprehensive set of criteria for the proposed model and weights representing the importance of each criterion were identified via questionnaires to specialists, deep discussions with experts, and making use of past studies. Chatterjee and Chakraborty (2013) explored in details the applicability, suitability, and potentiality of evaluation of mixed data (EVAMIX) method for solving the NCMP selection problems. Three illustrative examples were presented, which validated the usefulness of this method. In order to take into account the customers' requirements (product characteristics) as well as technical requirements (process characteristics) for a given NCMP selection problem, Prasad \& Chakraborty (2014) developed decisionmaking model while integrating quality function deployment (QFD). Recently, Roy et al. (2014) integrated fuzzy AHP and QFD for selecting best suited NCMP based on a set of product characteristics and process characteristics.

Although a good amount of research work has already been carried out by the past researchers on NCMPs selection, this paper attempts to investigate the applicability of an almost unexplored MCDM method, i.e. operational competitiveness ratings analysis (OCRA) method for solving the NCMPs selection problems. Till date, this method has very limited applications in the machining domain. The OCRA method helps select the most suitable NCMP for a given machining application based on different qualitative (ordinal) and quantitative (cardinal) criteria, such as tolerance and surface finish, power requirement, material removal rate, cost, efficiency, tooling and fixtures, tool consumption, safety, work material, shape feature, etc. In this paper, three case studies were solved to demonstrate its applicability and compare its ranking performance with other MCDM methods used by previous researchers.

\section{OCRA METHOD}

The OCRA method is a MCDM method which can be used to calculate relative performance of a set of competitive alternatives. The method uses an intuitive approach for incorporating the decision maker's preferences about the relative importance of the criteria (Parkan \& Wu, 1997). The OCRA method was developed by Parkan (1991) and later advocated by Parkan and $\mathrm{Wu}(1997,2000)$. It has been previously successfully applied to construct performance profiles for branch banks, software development teams, hotel and subway operations, and MCDM analysis of industrials robots, manufacturing industries and transport sector.

The main advantage of the OCRA method is that it can deal with those MCDM situations when the relative weights of the criteria are dependent on the alternatives and different weight distributions are assigned to the criteria for different alternatives, as well as some of the criteria are not applicable to all the alternatives (Chatterjee \& Chakraborty, 2012). This method has the advantage of treating beneficial (maximization) and non-beneficial (minimization) criteria separately, which helps the decision makers not to lose information during the decision-making process. Another major advantage of the 
OCRA method is that it is a nonparametric approach i.e. calculation procedure is not affected by the introduction of any additional parameters (e.g., $\mathrm{v}$ in VIKOR method and $\lambda$ in WASPAS method) as it happens in case of other MCDM methods. Also, regarding required application steps for solving decision making problems, the OCRA method has advantage over some other MCDM methods. While only six steps are needed to solve a particular decision making problem using the OCRA method, TOPSIS method for example requires nine steps (Venkata Rao, 2007).

The main idea of the OCRA method is to perform independent evaluation of alternatives with respect to beneficial and non-beneficial criteria, and finally to combine these two sets of ratings to obtain the operational competitiveness ratings. The main procedure of the OCRA method implementation consists of several steps (Parkan \& Wu, 2000; Chatterjee \& Chakraborty, 2012):

Step 1. Set the initial decision matrix, X:

$$
X=\left[x_{i j}\right]_{m \times n}=\left[\begin{array}{cccc}
x_{11} & x_{12} & \ldots & x_{1 n} \\
x_{21} & x_{22} & \ldots & x_{2 n} \\
\ldots & \ldots & \ldots & \ldots \\
x_{m 1} & x_{m 2} & \ldots & x_{m n}
\end{array}\right]
$$

where $x_{i j}$ is the performance score of $i$-th alternative with respect to $j$-th criterion, $m$ is the number of alternatives and $n$ is the number of criteria.

Step 2. In this step preference ratings with respect to the non-beneficial criteria are determined. The aggregate performance of $\mathrm{i}$ th alternative with respect to all nonbeneficial criteria is calculated using the following equation:

$\bar{I}_{i}=\sum_{k=1}^{q} w_{k} \cdot \frac{\max \left(x_{i}^{k}\right)-x_{i}^{k}}{\min \left(x_{i}^{k}\right)}, \quad(i=1,2, \ldots, m)$

where $q$ is the number of non-beneficial criteria, $\bar{I}_{i}$ is the measure of the relative performance of $i$-th alternative, $x_{i}^{k}$ is the performance score of $i$-th alternative with respect to $k$-th criterion and $w_{k}$ is weight of the $k$-th non-beneficial criterion. If $i$-th alternative is preferred over $m$-th alternative with respect to $k$-th criterion, then $x_{i}^{k}<x_{m}^{k}$.

Step 3. Determination of the linear preference rating for non-beneficial criteria by using the following equation:

$$
\overline{\bar{I}}_{i}=\bar{I}_{i}-\min \left(\bar{I}_{i}\right)
$$

Linear scaling is done to assign a zero rating to the least preferable alternative. $\overline{\bar{I}}_{i}$ represents the aggregate preference rating for $i$-th alternative with respect to the criteria.

Step 4. In this step preference ratings with respect to the beneficial criteria are determined. The aggregate performance of $i$ th alternative with respect to all beneficial criteria is calculated using the following equation:

$\bar{O}_{i}=\sum_{h=1}^{b} w_{h} \cdot \frac{x_{i}^{h}-\min \left(x_{i}^{h}\right)}{\min \left(x_{i}^{h}\right)}, \quad(i=1,2, \ldots, m)$

where $b$ is the number of beneficial criteria and $w_{h}$ is weight of the $h$-th beneficial criterion. The higher an alternatives score for a beneficial criterion, the higher is the preference for that alternative. 
Step 5. Determination of the linear preference rating for beneficial criteria by using the following equation:

$\overline{\bar{O}}_{i}=\bar{O}_{i}-\min \left(\bar{O}_{i}\right)$

Step 6. In this step the overall preference ratings of competitive alternatives are calculated using the following equation:

$P_{i}=\overline{\bar{I}}_{i}+\overline{\bar{O}}_{i}-\min \left(\overline{\bar{I}}_{m}+\overline{\bar{O}}_{m}\right)$

Based on the overall preference ratings the complete ranking of alternatives is obtained. The alternative with the highest overall performance rating receives the first rank.

\section{ILLUSTRATIVE EXAMPLES}

In order to demonstrate computation procedure and applicability of the OCRA method for solving NCMPs selection problems, the following three case studies are illustrated. In each case study the results obtained by previous researchers using different MCDM methods and the results obtained using the OCRA method were compared and discussed.

\subsection{Case study 1}

Chakladar and Chakraborty (2008) proposed combined approach using the TOPSIS and AHP methods for solving NCMP selection problem. This case study deals with the selection of the best NCMP that can efficiently machine precision holes on duralumin. The NCMP selection problem considers nine NCMPs (USM, WJM, AJM, ECM, CHM, EDM, WEDM, EBM and LBM) and ten criteria, i.e. tolerance and surface finish (TSF), power requirement (PR), material removal rate (MRR), cost (C), efficiency (E), tooling and fixtures (TF), tool consumption (TC), safety (S), work material (M) and shape feature (F). Among these criteria, TSF, PR and MRR are quantitative in nature, having absolute numerical values whereas $\mathrm{C}, \mathrm{E}, \mathrm{TF}, \mathrm{TC}, \mathrm{S}, \mathrm{M}$, and $\mathrm{F}$ have qualitative measures for which a ranked value judgment on a scale of 1-5 (1 is lowest, 3 is moderate, and 5 is the highest) is suggested (Chakladar \& Chakraborty, 2008). MRR, E, S, M and F are beneficial criteria where higher values are preferred, and on the other hand, TSF, PR, C, TF, and TC are nonbeneficial criteria where lower values are preferred. Based on the data from literature, Chakladar and Chakraborty (2008) developed the following decision matrix (Table 1).

Table 1. Decision matrix for case study 1 (Chakladar \& Chakraborty, 2008)

\begin{tabular}{ccccccccccc}
\hline & $\begin{array}{c}\text { TSF } \\
(\mu \mathrm{m})\end{array}$ & $\begin{array}{c}\text { PR } \\
(\mathrm{kW})\end{array}$ & $\begin{array}{c}\text { MRR } \\
\left(\mathrm{mm}^{3} / \mathrm{min}\right)\end{array}$ & $\mathrm{C}$ & $\mathrm{E}$ & $\mathrm{TF}$ & $\mathrm{TC}$ & $\mathrm{S}$ & $\mathrm{M}$ & $\mathrm{F}$ \\
\hline Goal & Min & Min & Max & Min & Max & Min & Min & Max & Max & Max \\
USM & 1 & 10 & 500 & 2 & 4 & 2 & 3 & 1 & 4 & 1 \\
WJM & 2.5 & 0.22 & 0.8 & 1 & 4 & 2 & 2 & 3 & 3 & 1 \\
AJM & 2.5 & 0.24 & 0.5 & 1 & 4 & 2 & 2 & 3 & 3 & 1 \\
ECM & 3 & 100 & 400 & 5 & 2 & 3 & 1 & 3 & 5 & 4 \\
CHM & 3 & 0.4 & 15 & 3 & 3 & 2 & 1 & 3 & 5 & 4 \\
EDM & 3.5 & 2.7 & 800 & 3 & 4 & 4 & 4 & 3 & 4 & 5 \\
WEDM & 3.5 & 2.5 & 600 & 3 & 4 & 4 & 4 & 3 & 4 & 5 \\
EBM & 2.5 & 0.2 & 1.6 & 4 & 5 & 2 & 1 & 3 & 4 & 1 \\
LBM & 2 & 1.4 & 0.1 & 3 & 5 & 2 & 1 & 1 & 4 & 1 \\
\hline
\end{tabular}


Using the AHP method, Chakladar and Chakraborty (2008) determined the criteria weights as: $\mathrm{w}_{\mathrm{TSF}}=0.0783, \mathrm{w}_{\mathrm{PR}}=0.0611$, $\mathrm{w}_{\mathrm{MRR}}=0.1535, \mathrm{w}_{\mathrm{C}}=0.1073, \mathrm{w}_{\mathrm{E}}=0.0383$, $\mathrm{w}_{\mathrm{TF}}=0.0271, \mathrm{w}_{\mathrm{TC}}=0.0195 . \mathrm{w}_{\mathrm{S}}=0.0146$, $\mathrm{w}_{\mathrm{M}}=0.2766$ and $\mathrm{w}_{\mathrm{F}}=0.2237$. The same criteria weights were used for the OCRA method-based analysis.

By using Equation (2), the aggregate performances of the alternatives with respect to all non-beneficial criteria are calculated. Based on obtained values and by applying Equation (3) the linear preference ratings for all non-beneficial criteria are determined. Similarly, by applying Equations (4) and (5), aggregate performances and the linear preference ratings for the alternatives on all beneficial criteria are calculated. Finally, by using Equation (6) the overall preference ratings for competitive alternatives are obtained. The computational details of the OCRA method are shown in Table 2.As could be seen from Table 2 by applying the OCRA method, the complete ranking of competitive NCMPs is obtained as 3-7-8-45-1-2-6-9. EDM is observed to be the most appropriate NCMP for this machining application. WEDM process has the second preference and LBM is the least favored NCMP. The ranking performances of the OCRA method with respect to those derived by past researchers are given in Table 3 .

As could be seen from Table 3 application of different MCDM methods proposes EDM as the most appropriate NCMP for this given machining application. When compared with the results derived by Chakladar and Chakraborty (2008), Karande and Chakraborty (2012) and Chaterjee and Chakraborty (2012), the values of Spearman's rank correlation coefficient $\left(r_{s}\right)$

Table 2. Computational details for case study 1

\begin{tabular}{ccccccc}
\hline & $\bar{I}_{i}$ & $\overline{\bar{I}}_{i}$ & $\bar{O}_{i}$ & $\overline{\bar{O}}_{i}$ & $P_{i}$ & Rank \\
\hline USM & 5.5143 & 5.4031 & 767.4770 & 767.3274 & 772.7304 & 3 \\
WJM & 6.0615 & 5.9503 & 1.1420 & 0.9924 & 6.9427 & 7 \\
AJM & 6.0604 & 5.9492 & 0.6815 & 0.5319 & 6.4811 & 8 \\
ECM & 0.1112 & 0 & 614.7312 & 614.5816 & 614.5816 & 4 \\
CHM & 5.8174 & 5.7062 & 23.7754 & 23.6257 & 29.3319 & 5 \\
EDM & 5.5661 & 5.4549 & 1228.9010 & 1228.7514 & 1234.2063 & 1 \\
WEDM & 5.5771 & 5.4659 & 921.9010 & 921.7514 & 927.2173 & 2 \\
EBM & 5.7602 & 5.6490 & 2.4814 & 2.3317 & 7.9807 & 6 \\
LBM & 5.8407 & 5.7295 & 0.1497 & 0 & 5.7295 & 9 \\
\hline
\end{tabular}

Table 3. Rankings of the competitive NCMPs obtained using different MCDM methods

\begin{tabular}{ccccc}
\hline & $\begin{array}{c}\text { Combined TOPSIS and AHP } \\
\text { (Chakladar \& Chakraborty, } \\
\text { (C) }\end{array}$ & OCRA & $\begin{array}{c}\text { PROMETHEE } \\
\text { (Karande \& Chakraborty } \\
\text { 2012) }\end{array}$ & $\begin{array}{c}\text { EVAMIX } \\
\text { (Chaterjee \& Chakraborty, } \\
\text { 2012) }\end{array}$ \\
\hline USM & 5 & 3 & 4 & 6 \\
WJM & 8 & 7 & 8 & 8 \\
AJM & 9 & 8 & 9 & 9 \\
ECM & 2 & 4 & 3 & 4 \\
CHM & 4 & 5 & 7 & 3 \\
EDM & 1 & 1 & 1 & 1 \\
WEDM & 3 & 2 & 2 & 2 \\
EBM & 6 & 6 & 5 & 7 \\
LBM & 7 & 9 & 6 & 5 \\
\hline
\end{tabular}


for the OCRA method were computed as $0.87,0.85$ and 0.73 , respectively. This shows similar ranking performance of these MCDM methods for this particular machining application.

\subsection{Case study 2}

In this example, surface of revolution feature is to be generated on stainless steel work material. To select the most appropriate NCMP for generating surface of revolution the same criteria as in previous case study were considered. The original decision matrix of this NCMP selection problem is given in Table 4.

Chakladar and Chakraborty (2008) used the same criteria weights as in case study 1. Hence, these are also used here for the OCRA method-based analysis.

Now, the same NCMP selection problem is solved using the OCRA method. Again, by using Equation (2), the aggregate performances of the alternatives with respect to all non-beneficial criteria are calculated. Based on obtained values and by applying Equation (3) the linear preference ratings for all non-beneficial criteria are determined. Similarly, by applying Equations (4) and (5), aggregate performances and the linear preference ratings for the alternatives on all beneficial criteria are calculated. Finally, by using Equation (6) the overall preference ratings for competitive alternatives are obtained. The computational details of the OCRA method are shown in Table 5.

As could be seen from Table 5 by applying the OCRA method, the complete ranking of competitive NCMP is obtained as 3-7-8-4-5-1-2-6-9. EDM is observed to be the most appropriate NCMP for this machining application. WEDM process has

Table 4. Decision matrix for case study 2 (Chakladar \& Chakraborty, 2008)

\begin{tabular}{ccccccccccc}
\hline & $\begin{array}{c}\text { TSF } \\
(\mu \mathrm{m})\end{array}$ & $\begin{array}{c}\mathrm{PR} \\
(\mathrm{kW})\end{array}$ & $\begin{array}{c}\text { MRR } \\
\left(\mathrm{mm}^{3} / \mathrm{min}\right)\end{array}$ & $\mathrm{C}$ & $\mathrm{E}$ & $\mathrm{TF}$ & $\mathrm{TC}$ & $\mathrm{S}$ & $\mathrm{M}$ & $\mathrm{F}$ \\
\hline Goal & Min & Min & Max & Min & Max & Min & Min & Max & Max & Max \\
USM & 1 & 10 & 500 & 2 & 4 & 2 & 3 & 1 & 4 & 1 \\
WJM & 2.5 & 0.22 & 0.8 & 1 & 4 & 2 & 2 & 3 & 4 & 1 \\
AJM & 2.5 & 0.24 & 0.5 & 1 & 4 & 2 & 2 & 3 & 4 & 1 \\
ECM & 3 & 100 & 400 & 5 & 2 & 3 & 1 & 3 & 5 & 4 \\
CHM & 3 & 0.4 & 15 & 3 & 3 & 2 & 1 & 3 & 5 & 1 \\
EDM & 3.5 & 2.7 & 800 & 3 & 4 & 4 & 4 & 3 & 5 & 1 \\
WEDM & 3.5 & 2.5 & 600 & 3 & 4 & 4 & 4 & 3 & 5 & 1 \\
EBM & 2.5 & 0.2 & 1.6 & 4 & 5 & 2 & 1 & 3 & 4 & 1 \\
LBM & 2 & 1.4 & 0.1 & 3 & 5 & 2 & 1 & 1 & 4 & 1 \\
\hline
\end{tabular}

Table 5. Computational details for case study 2

\begin{tabular}{ccccccc}
\hline & $\bar{I}_{i}$ & $\overline{\bar{I}}_{i}$ & $\bar{O}_{i}$ & $\overline{\bar{O}}_{i}$ & $P_{i}$ & Rank \\
\hline USM & 5.5143 & 5.4031 & 767.4770 & 767.3274 & 772.7304 & 3 \\
WJM & 6.0615 & 5.9503 & 1.2342 & 1.0846 & 7.0349 & 7 \\
AJM & 6.0604 & 5.9492 & 0.7737 & 0.6241 & 6.5733 & 8 \\
ECM & 0.1112 & 0 & 614.7312 & 614.5816 & 614.5816 & 4 \\
CHM & 5.8174 & 5.7062 & 23.1043 & 22.9546 & 28.6608 & 5 \\
EDM & 5.5661 & 5.4549 & 1228.0984 & 1227.9488 & 1233.4037 & 1 \\
WEDM & 5.5771 & 5.4659 & 921.0984 & 920.9488 & 926.4147 & 2 \\
EBM & 5.7602 & 5.6490 & 2.4814 & 2.3317 & 7.9807 & 6 \\
LBM & 5.8407 & 5.7295 & 0.1497 & 0 & 5.7295 & 9 \\
\hline
\end{tabular}


the second preference and LBM is the least favored NCMP.

For solving NCMP selection problem Chakladar and Chakraborty (2008) and Chaterjee and Chakraborty (2012) applied combined approach using the TOPSIS and AHP method and EVAMIX method, respectively. The comparison of obtained performance rankings is given in Table 6 .

On the basis of the results given in Table 6 it is observed that a very high rank correlation between the OCRA and combined TOPSIS and AHP methods exists (Spearman's rank correlation coefficient of $r_{s}$ $=0.83$ ). It can be also observed that, the best and the worst choices of NCMPs remain the same in the case of combined TOPSIS and AHP and EVAMIX methods. However, the ranking of certain alternative NCMPs obtained by the OCRA method is different from that reported by Chaterjee and Chakraborty (2012).

EDM is the first choice based on the OCRA method, whereas it was ECM in Chaterjee and Chakraborty (2012) and Chakladar and Chakraborty (2008) and EDM was proposed as the fifth and second choice, respectively. A closer look at the quantitative data for EDM and ECM (Table 4) reveals that EDM is better than ECM in the case of four criteria (PR, MRR, C and E) which have total sum of criteria weights of 0.36. EDM is equal to ECM in the case of two criteria ( $S$ and M). Finally, ECM is better than EDM also in the case of four criteria (TSF, TF, TC and $F$ ) which have total sum of criteria weights of 0.35 . Therefore, considering relative importance of criteria proposing EDM as the first choice may be justified.

\subsection{Case study 3}

Chakladar et al. (2009) presented a digraph-based approach for NCMPs selection. This case study considers deep through cutting operation performed on titanium. Six most important criteria, like tolerance and surface finish (TSF), material removal rate (MRR), power requirement $(\mathrm{PR})$, cost $(\mathrm{C})$, shape feature (F) and work material type $(\mathrm{M})$ were considered in the analysis. Among these criteria, MRR, F and $\mathrm{M}$ are beneficial criteria. The quantitative assessments of alternative NCMP with respect to considered criteria are given in Table 7.

The criteria weights were calculated as (Karande \& Chakraborty, 2012): $\mathrm{w}_{\mathrm{TSF}}=$ $0.03, \mathrm{w}_{\mathrm{MRR}}=0.36, \mathrm{w}_{\mathrm{PR}}=0.03, \mathrm{w}_{\mathrm{C}}=0.04, \mathrm{w}_{\mathrm{F}}$ $=0.13$ and $\mathrm{w}_{\mathrm{M}}=0.40$ and are considered here for the subsequent analyzes.

Now, the same NCMP selection problem is solved using the OCRA method. All calculations were done using Equations (2-6)

Table 6. Rankings of the competitive NCMPs obtained using different MCDM methods

\begin{tabular}{cccc}
\hline & OCRA & $\begin{array}{c}\text { Combined TOPSIS and AHP } \\
\text { (Chakladar \& Chakraborty, 2008) }\end{array}$ & $\begin{array}{c}\text { EVAMIX } \\
\text { (Chaterjee \& Chakraborty, 2012) }\end{array}$ \\
\hline USM & 3 & 4 & 3 \\
WJM & 7 & 8 & 7 \\
AJM & 8 & 9 & 9 \\
ECM & 4 & 1 & 1 \\
CHM & 5 & 6 & 8 \\
EDM & 1 & 2 & 5 \\
WEDM & 2 & 3 & 6 \\
EBM & 6 & 5 & 4 \\
LBM & 9 & 7 & 2 \\
\hline
\end{tabular}


Table 7. Decision matrix for case study 3 (Chakladar et al. 2009)

\begin{tabular}{ccccccc}
\hline & $\begin{array}{c}\text { TSF } \\
(\mu \mathrm{m})\end{array}$ & $\begin{array}{c}\text { MRR } \\
\left(\mathrm{mm}^{3} / \mathrm{min}\right)\end{array}$ & PR $(\mathrm{kW})$ & $\mathrm{C}$ & $\mathrm{F}$ & $\mathrm{M}$ \\
\hline AJM & 2.5 & 0.8 & 0.22 & 1 & 1 & 4 \\
USM & 1 & 300 & 2.4 & 2 & 1 & 4 \\
CHM & 3 & 15 & 0.4 & 3 & 1 & 4 \\
EBM & 2.5 & 1.6 & 0.2 & 4 & 4 & 4 \\
LBM & 2 & 0.1 & 1.4 & 3 & 4 & 4 \\
ECM & 3 & 1500 & 100 & 5 & 5 & 4 \\
EDM & 3.5 & 800 & 2.7 & 3 & 1 & 5 \\
PAM & 5 & 75000 & 50 & 1 & 5 & 4 \\
\hline
\end{tabular}

Table 8. Computational details for case study 3

\begin{tabular}{ccccccc}
\hline & $\bar{I}_{i}$ & $\overline{\bar{I}}_{i}$ & $\bar{O}_{i}$ & $\overline{\bar{O}}_{i}$ & $P_{i}$ & Rank \\
\hline AJM & 15.2020 & 15.1420 & 2.5200 & 2.1300 & 17.2720 & 7 \\
USM & 14.8800 & 14.8200 & 1079.6400 & 1079.2500 & 1094.0700 & 4 \\
CHM & 15.0800 & 15.0200 & 53.6400 & 53.2500 & 68.2700 & 5 \\
EBM & 15.0850 & 15.0250 & 5.7900 & 5.4000 & 20.4250 & 6 \\
LBM & 14.9600 & 14.9000 & 0.3900 & 0.0000 & 14.9000 & 8 \\
ECM & 0.0600 & 0.0000 & 5400.1600 & 5399.7700 & 5399.7700 & 2 \\
EDM & 14.7200 & 14.6600 & 2879.7400 & 2879.3500 & 2894.0100 & 3 \\
PAM & 7.6600 & 7.6000 & 270000.1600 & 269999.7700 & 270007.3700 & 1 \\
\hline
\end{tabular}

and the computational details are given in Table 8.

As could be seen from Table 8 by applying the OCRA method, the complete ranking of competitive NCMPs is obtained as 7-4-5-6-8-2-3-1. PAM is observed to be the most appropriate NCMP for this machining application followed by ECM. LBM is the least favored NCMP in this case. The ranking performances of the OCRA method with respect to those derived by past researchers are given in Table 9.

As could be seen from Table 9 there exists a very high rank correlation between the rankings of OCRA and PROMETHEE methods with Spearman's rank correlation coefficient of $r_{s}=0.98$. However, the ranking of certain alternative NCMPs obtained by OCRA and PROMETHEE methods is different from that reported by Chakladar et al. (2009). For example, ECM is the second choice based on the OCRA method, whereas it was EBM in Chakladar et al. (2009) and ECM was proposed as the sixths choice by authors. A closer look at the quantitative data for ECM and EBM (Table 7) reveals that

Table 9. Rankings of the competitive NCMP obtained using different MCDM methods

\begin{tabular}{cccc}
\hline & OCRA & $\begin{array}{c}\text { Digraph-based approach } \\
\text { (Chakladar et al., 2009) }\end{array}$ & $\begin{array}{c}\text { PROMETHEE } \\
\text { (Karande and Chakraborty, 2012) }\end{array}$ \\
\hline AJM & 7 & 3 & 7 \\
USM & 4 & 5 & 4 \\
CHM & 5 & 7 & 6 \\
EBM & 6 & 2 & 5 \\
LBM & 8 & 4 & 8 \\
ECM & 2 & 6 & 2 \\
EDM & 3 & 8 & 3 \\
PAM & 1 & 1 & 1 \\
\hline
\end{tabular}


ECM is better than EBM in the case of MRR and $\mathrm{F}$ criteria, and equal to EBM in the case $\mathrm{M}$ criterion. EBM is better than ECM in the case of TSF, PR and C criteria. However, considering relative importance of criteria i.e. criteria weights, proposing ECM as the second choice seems to be justified. It may be added here, however, that the criteria weights used by Chakladar et al. (2008) were different from those used in the present work. Thereby, the differences in the ranking of competitive NCMPs between the OCRA method and that suggested by Chakladar et al. (2008) can be explained.

\section{CONCLUSIONS}

Selection of suitable NCMP for a given machining application is a difficult task for the process engineers due to limited theoretical and practical knowledge, as well as complexity of NCMPs. A large number of mathematical methods and procedures have been proposed to facilitate decision making process and assist in systematical selection and ranking of competitive NCMPs. This paper introduces the OCRA method approach, which helps the process engineers in selecting the most suitable NCMP from a large number of competitive alternatives. Three case studies demonstrated the potentiality, applicability and usefulness of the OCRA method through solving complex NCMP selection problems. OCRA method can simultaneously take into account large number of criteria as well as alternatives, offering very simple and computationally efficient approach by using fewer formulations. As the NCMP selection problems consist of both the qualitative and quantitative criteria, the OCRA method is quite suitable to deal with these types of decision making problems. A major advantage of the OCRA method its calculation procedure is not affected by the introduction of any additional parameters as it happens in case of other MCDM methods. A comparative analysis with the other already developed MCDM methods showed a good correlation with those obtained by the past researchers, proving its acceptability and strength for application in solving NCMPs selection problems. Slight discrepancies between the rankings of the alternatives may be attributed due to the subjective judgments taken by the decision makers.

Main scope of future work will be application and comparative analysis of the OCRA method for solving selection problems in manufacturing environment and design of an OCRA based expert system with a graphical user interface to ease the decision making process.

\section{Acknowledgements}

This work was carried out within the project TR 35034 financially supported by the Ministry of Education and Science of the Republic of Serbia.

\section{References}

Chakladar, N.D., \& Chakraborty, S. (2008). A combined TOPSIS-AHP-methodbased approach for non-traditional machining processes selection. Proceedings of the Institution of Mechanical Engineers, Part B: Journal of Engineering Manufacture, 222 (12), 1613-1623.

Chakladar, N.D., Das, R., \& Chakraborty, S. (2009). A digraph-based expert system for non-traditional machining processes selection. International Journal of Advanced 


\title{
ИЗБОР НЕКОНВЕНЦИОНАЛНЕ ТЕХНОЛОГИЈЕ ОБРАДЕ ПРИМЕНОМ МЕТОДЕ “ОСRА"
}

\author{
Милош Мадић, Душан Петковић, Мирослав Радовановић
}

\begin{abstract}
Извод
Избор најпогодније неконвенционалне технологије обраде за дату примену може се посматрати као проблем вишекритеријумског одлучивања који укључује различите, а често и конфликтне критеријуме. За решавање проблема избора развијене су различите методе вишекритеријумског одлучивања. У овом раду приказана је примена релативно неистражене методе вишекритеријумског одлучивања, методе „OCRA“, за решавање проблема избора неконвенционалне технологије обраде. Примењивост, подобност и рачунска процедура методе „OCRA“ је илустрована решавањем три студије случаја које се баве избором најпогодније неконвенционалне технологије обраде. У оквиру сваке студије случаја добијене ранг листе су упоређене са ранг листама које су одређене од стране других истраживача применом различитих метода вишекритеријумског одлучивања. Добијени резултати рангирања имају добру корелацију са претходним резултатима што потврђује корисност ове методе за решавање сложених проблема избора неконвенционалне технологије обраде.
\end{abstract}

Кључне речи: неконвенционалне технологије обраде, вишекритеријумско одлучивање, метода "OCRA"

Manufacturing Technology, 43 (3-4), 226237.

Chakraborty, S., \& Dey, S. (2006). Design of an analytic-hierarchy-process-based expert system for non-traditional machining process selection. International Journal of Advanced Manufacturing Technology, 31 (56), 490-500.

Chakraborty, S. (2011). Applications of the MOORA method for decision making in manufacturing environment. International Journal of Advanced Manufacturing Technology, 54 (9-12), 1155-1166.

Chatterjee, P., \& Chakraborty, S. (2012). Material selection using preferential ranking methods. Materials and Design, 35 (1), 384393.

Chatterjee, P., \& Chakraborty, S. (2013). Nontraditional machining processes selection using evaluation of mixed data method. International Journal of Advanced Manufacturing Technology, 68 (5-8), 16131626.

Das, S., \& Chakraborty, S. (2011). Selection of non-traditional machining processes using analytic network process. Journal of Manufacturing Systems, 30 (1), 41-53.

Hajkowicz, S., \& Higgins, A. (2008). A comparison of multiple criteria analysis techniques for water resource management. European Journal of Operational Research, 184 (1), 255-265.

Kalpakjian, S., \& Schmid, S.R. (2000). Manufacturing engineering and technology. New York, Prentice Hall.

Karande, P., \& Chakraborty, S. (2012). Application of PROMETHEE-GAIA method for non-traditional machining processes selection. Management Science 
Letters, 2 (6), 2049-2060.

Kovačević, M., Madić, M., Radovanović, M., \& Rančić, D. (2014). Software prototype for solving multi-objective machining optimization problems: application in nonconventional machining processes. Expert Systems with Applications, 41 (13), 56575668.

Parkan, C. (1991). The calculation of operational performance ratings. International Journal of Production Economics, 24 (1), 165-173.

Parkan, C., \&, Wu, M.L. (1997). On the equivalence of operational performance measurement and multiple attribute decision making. International Journal of Production Research, 35 (11), 2963-88.

Parkan, C., \&, Wu, M.L. (2000). Comparison of three modern multi criteria decision-making tools. International Journal of Systems Science, 31 (4), 497-517.

Prasad, K., \& Chakraborty, S. (2014). A decision-making model for non-traditional machining processes selection. Decision Science Letters, 3 (4), 467-478.

Roy, M.K., Ray, A., \& Pradhan, B.B. (2014). Non-traditional machining process selection using integrated fuzzy AHP and QFD techniques: a customer perspective. Production \& Manufacturing Research, 2 (1), 530-549.

Sadhu, A., \& Chakraborty, S. (2011). Non-traditional machining processes selection using data envelopment analysis (DEA). Expert Systems with Applications, 38 (7), 8770-8781.

Samanta, S., \& Chakraborty, S. (2011). Parametric optimization of some nontraditional machining processes using artificial bee colony algorithm. Engineering Applications of Artificial Intelligence, 24 (6), 946-957.

Stanujkić, D., Đorđević, B., \& Đorđević,
M. (2013). Comparative analysis of some prominent MCDM methods: a case of ranking Serbian banks. Serbian Journal of Management, 8 (2), 213-241.

Temuçin, T., Tozan, H., Valíček, J., \& Harničárová, M. (2013). A fuzzy based decision support model for non-traditional machining process selection. Technical Gazette, 20 (5), 787-793.

Venkata Rao, R. (2007). Decision Making in the Manufacturing Environment: using graph theory and fuzzy multiple attribute decision making methods. Springer-Verlag.

Yurdakul, M., \& Cogun, C. (2003). Development of a multi-attribute selection procedure for nontraditional machining processes. Proceedings of the Institution of Mechanical Engineers, Part B: Journal of Engineering Manufacture, 217 (7), 9931009. 